\title{
Assédio moral nas organizações de trabalho: perversão e sofrimento
}

\author{
Angela Maria Pires Caniato ${ }^{1}$ e Eliane da Costa Lima $^{2}$ \\ Universidade Estadual de Maringá
}

\begin{abstract}
Este estudo pretende apresentar as articulações dos dados de uma pesquisa bibliográfica cujo objetivo primordial foi gerar reflexões que venham, de alguma forma, contribuir para o debate sobre as conseqüências na subjetividade do trabalho no contexto socioeconômico contemporâneo. Emerge como foco de discussão o assédio moral nas organizações de trabalho. Realiza-se uma abordagem do trabalho em termos conceituais, considerando o contexto e a historicidade como essenciais para o alcance do objetivo proposto. Explicita-se uma caracterização dos modos de produção capitalistas e, posteriormente, uma apresentação do assédio moral, de acordo com a abordagem de MaryFrance Hirigoyen, bem como o de seu equivalente em Christophe Dejours. Em última instância, buscou-se demonstrar as aproximações e os distanciamentos sob essas duas perspectivas quanto ao fenômeno assédio moral no trabalho.
\end{abstract}

Palavras-chave: Trabalho, Assédio moral, Perversão, Cinismo viril, Sofrimento psicossocial.

Harassment in work organizations: perversion and pain

The current analysis provides data collected from a bibliographical research aimed at provoking reflections that may somehow contribute towards a debate on the subjectivity consequences of work in the contemporary social and economical context. Discussion is focused on moral harassment in work organizations. Concepts are analyzed taking into consideration context and historicity as essential to obtain the above aim. The modes of capitalist production are highlighted, coupled to a presentation of moral harassment according to the approaches by Mary-France Hirigoyen and Christophe Dejours. Approximations and distancing of these two points of view are demonstrated with regard to moral harassment in the work environment.

Keywords: Work, Moral harassment, Perversion, Virile cynicism, Psychosocial pain.

\section{Introdução}

$\mathrm{O}$ fenômeno denominado assédio moral no trabalho em pouco tempo conseguiu ampla repercussão e tem mobilizado, simultaneamente, os meios jornalísticos, organizacionais, sindicais, médicos, jurídicos e acadêmicos em diversas áreas, inclusive na psicologia. É preciso, entretanto, ter cuidado para não banalizar o assunto e torná-lo simplesmente mais um tema da moda, que, em um tempo ainda menor, perde-se na irrelevância teórica e na esterilidade prática.

Considera-se imprescindível, portanto, que a análise desse fenômeno psicossocial comporte elementos que permitam a sua definição e identificação no espaço histórico-cultural em que se delineia e concretiza-se, visando, assim, a entender suas imbricações nas relações sociais vigentes. Esse parece ser o caminho mais viável na busca pela superação dos limites de uma compreensão baseada estritamente em indivíduos isolados, a qual invariavelmente leva à culpabilização dos sujeitos e ao velamento da responsabilidade social.

1 Professora Doutora do Mestrado de Psicologia da Universidade Estadual de Maringá. Psicóloga clínica de base psicanalítica.

2 Acadêmica do Mestrado em Psicologia da Universidade Estadual de Maringá. Psicóloga especializada na área de recursos humanos. 
Nessa perspectiva, o estudo realizado firma-se em uma concepção do homem enquanto ator social, sujeito que se constrói por sua atividade criadora e produtiva, que se constitui no movimento dialético entre o cultural e a história, ser relacional que, ao negar o outro, no individualismo, esvazia-se de sentido.

Em última instância, o que aqui se propõe é contribuir para o debate sobre o sofrimento psíquico do homem no mundo do trabalho, tendo como eixo de análise o assédio moral, segundo as abordagens de Hirigoyen e de Dejours.

Entende-se como primordial, mesmo que redundante, introduzir a discussão apresentando o conceito de trabalho e pontuando as transformações da organização do trabalho na sociedade moderna, visando, sobretudo, reafirmar a relevância de tais fatores enquanto concorrentes para o sofrimento do homem na contemporaneidade.

\section{O trabalho}

Do ponto de vista etimológico, a palavra trabalho origina-se do latim tripaliare, que significa "torturar". Por seu turno, o termo é derivado de tripalium (instrumento de tortura composto por três paus). Da idéia inicial de sofrer, passou-se para a idéia de esforçar-se, lutar, pugnar, e, por fim, trabalhar (Cunha, 1986, p. 779).

Considerando-se especificamente a dimensão humana, trabalho é um conceito que pode reportar a definições elaboradas desde o século IV antes de Cristo, na Grécia. De acordo com Aristóteles, o trabalho é uma das três atividades especificamente humanas por meio da qual o homem desenvolve-se e se humaniza-se. As outras duas são a atividade teórica (visa obter conhecimento da natureza) e a práxis (visa o agir ético do sujeito social) (Carone, 2005).

No sentido aristotélico, o trabalho é a atividade humana com finalidade inerente à produção de um mundo para os homens. É agindo sobre o mundo externo, ou seja, é trabalhando que o homem transforma a natureza, impõe formas novas e artificiais às coisas que o rodeiam, criando um mundo para si, um mundo humanizado.

Sob esse ponto de vista, a atividade humana só é trabalho se houver a síntese entre o pensamento e a ação. Desde o momento em que o homem planeja, idealiza e estabelece uma finalidade preliminar e subjetiva para sua atividade, que é anterior à ação, ao gesto, até a consecução do fazer propriamente dito, realizado por intermédio de instrumentos. O resultado final é o produto no qual se objetiva, materializa-se a intenção e a finalidade do sujeito da ação. Entretanto, havendo alteração ou incongruência nesse processo, não há trabalho, há banausia: atividade humana esvaziada de sentido subjetivo.

(...) O escravo, a rigor, não "trabalha" porque aquilo que ele fez, o fez porque o senhor determinou o plano e o objetivo do produto; agiu como um instrumento da vontade do senhor e não como sujeito livre da ação-trabalho (...) então sua atividade é banausia, como a de qualquer instrumento não-vivo (enxada, martelo etc.) comandado por uma finalidade externa a ele (...), reduzindo o trabalho à condição de trabalho vazio de finalidade subjetiva (não-trabalho) (Carone, 2005, pp. 2-3).

Na acepção de Marx, o trabalho é um processo em que a atividade está voltada para a produção de valor de uso, visando à satisfação das necessidades humanas. Seu significado é qualitativo e refere-se à utilidade do resultado do trabalho. Porém, esse resultado inclui o processo de produção, que se relaciona ao dispêndio de energia humana, assumindo um significado quantitativo, e pressupondo um modo definido de relações de produção que 
determinam as condições sociais nas quais se realiza o trabalho em dado momento histórico (Liedke, 2002).

O trabalho alienado, conforme definido por Marx nos Manuscritos de Paris (1844), pode ser equiparado à descrição de banausia feita por Aristóteles, ou seja, o trabalho torna-se alienado à medida que sua finalidade não é subjetiva, nem autônoma, nem livre, mas sim, heterônoma e não livre. Posteriormente, em O Capital (1867), Marx toma o trabalho em um sentido sócio-histórico, enquanto atividade produtora de valor econômico e subordinada à valorização do capital. $\mathrm{O}$ trabalho nesse contexto

(...) está alienado ao processo de valorização, como finalidade heterônoma dos agentes da produção. Essa alienação não recai apenas sobre o trabalhador, mas também sobre a classe proprietária dos meios de produção. É a sociedade como um todo que está alienada (...) (Carone, 2005, p. 3).

Do ponto de vista da psicodinâmica do trabalho, o trabalho não se refere apenas a uma relação social, ao emprego estrutural ou a uma atividade de produção. Para Dejours (2006), o trabalho em sua dimensão humana implica uma ação, isto é, implica o ato de trabalhar:

(...) o trabalho é aquilo que implica (...) gestos, saber-fazer, um engajamento do corpo, a mobilização da inteligência, a capacidade de refletir, de interpretar e de reagir às situações; é o poder de sentir, de pensar, de inventar, (...) um certo modo de engajamento da personalidade para responder a uma tarefa delimitada por pressões (materiais e sociais) (Dejours, 2006, p. 1).

\section{Os modos de produção}

Marx e Engels em A ideologia alemã (1845) examinam detalhadamente a divisão do trabalho na manufatura e na fábrica, bem como, sua importância na dinâmica capitalista. Inúmeros estudos de diversas áreas (história, sociologia, antropologia, psicologia), respaldados nos referenciais teórico-metodológicos de suas obras, demonstram que a ênfase nos aspectos físicos e utilitários do trabalho humano, enquanto atividade econômica, separada de outras dimensões da vida social e individual, é determinada pela hegemonia econômica e ideológica da burguesia.

Entre os séculos XVIII e XIX, na efervescência do contexto sócio-político-econômico da Revolução Industrial e da Revolução Francesa, permeado pelo advento do capitalismo, é que floresce a cultura burguesa apoiada nos princípios de liberdade de mercado, de autodeterminação individual e de racionalidade científica. Os ditames da herança são substituídos pelos ditames da produção: o poder do novo capital sobrepõe-se à tradição hierárquica secular. A trama econômico-social passa a depender da capacidade de apropriação do trabalho alheio, a mais-valia dá-se, então, na proporção em que o trabalho do homem puder ser colocado sob controle.

Os princípios desenvolvidos e sistematizados pelo engenheiro norte-americano Frederick Winslow Taylor (1911) são: separação programada entre a concepção (administradores, gerentes) e execução das tarefas (operários), a intensificação da divisão do trabalho e o estímulo ao desempenho produtivo (salários e prêmios por produção). Esses princípios atendem ao interesse dos capitalistas de reduzir a autonomia dos operários. Pouco tempo depois, em 1913, Henry Ford, empresário da indústria automobilística norte-americana, agrega uma nova dimensão à racionalização preconizada por Taylor. Conjugando o acirramento da divisão entre trabalho manual e intelectual com a extensa e especializada mecanização 
emergente, inaugura o que veio representar o paradigma explicativo do regime de acumulação ao longo de várias décadas do século XX: o fordismo.

A consolidação do processo de trabalho taylorista-fordista trouxe consigo a ilusão de que o sistema de metabolismo social do capital pudesse ser controlado e regulado por um "compromisso" entre capital, trabalho e Estado. Os elementos firmadores desse compromisso seriam os sindicatos (representantes oficiais dos trabalhadores), os partidos políticos, o patronato, cabendo ao Estado um papel de neutralidade, um sentido arbitral de exterioridade frente ao capital e ao trabalho. Contudo, se, por um lado, os mecanismos desse "compromisso" garantiram ganhos sociais e seguridade para os trabalhadores dos países centrais, por outro lado, constituíram um meio efetivo de delimitar o campo da luta de classes, desarticulando o movimento operário por meio da institucionalização dos organismos sindicais e políticos. Entretanto, os sindicatos, ao adotarem a via contratualista, tendo como finalidade as práticas da 'negociação', tornam-se parte do mecanismo de controle capitalista sobre o proletariado.

A sociabilidade fundada no compromisso fordista revela, então, um operário homogeneizado (o "operário-massa") em suas condições de existência, não só devido à fragmentação e à desqualificação de seu trabalho, mas também devido à ilusão do compromisso social-democrata.

No final da década de 60, inicia-se a chamada crise do fordismo. Aparece como uma crise econômica, que se expressa essencialmente na queda da taxa de lucro. Seu núcleo, entretanto, é marcado pelo esgotamento do padrão de acumulação taylorista-fordista de produção (a lógica decrescente do valor de uso da mercadoria) e pelo conseqüente desmoronamento dos mecanismos de regulação social vigentes. Nesse sentido, se o operáriomassa foi a base social para a expansão do compromisso social-democrático anterior, ele foi também o seu principal elemento de transbordamento, ruptura e confrontação (Bihr, citado por Antunes, 2005).

O capital encontra no desenvolvimento tecnológico (Terceira Revolução Industrial) o aliado para a confrontação aberta à crise. Inicia-se, assim, um processo de reorganização do capital e de seu sistema político-ideológico. O advento do neoliberalismo, com a "privatização" do Estado, a desregulamentação dos direitos do trabalhador e a desmontagem do setor produtivo estatal, associado ao processo de reestruturação da produção e do trabalho, instrumentalizam o capital para recompor os patamares de sua expansão.

A atual fase de reestruturação produtiva, iniciada nos anos 70 do século passado, tem como modelo de organização do trabalho a experiência japonesa conhecida por toytismo. $\mathrm{O}$ toyotismo ou ohnismo, criado na fábrica Toyota pelo engenheiro Kiichiro Ohno, surge como via alternativa de expansão e consolidação do capitalismo monopolista industrial no Japão dos anos 50, tendo em vista sua demanda interna específica e a economia debilitada e sucateada pela Segunda Guerra Mundial. Impulsionado pelos avanços da microeletrônica e pela crise estrutural do capital, o toyotismo disseminou-se, com diversas nuanças, pelo mundo industrializado, significando uma alternativa para os problemas enfrentados pelo capitalismo ocidental.

De fato, o toyotismo traz para o espaço do processo produtivo novos elementos e técnicas de organização do trabalho, que atendem ao padrão de acumulação flexível do capital, como por exemplo: o trabalho em equipe (team work), no qual todos têm funções múltiplas; os estoques mínimos (just in time), que devem ser supridos no tempo certo e na quantidade exata, utilizando o kanban (senha ou cartão), procedimento pelo qual cada setor informa ao anterior a quantidade que deve ser produzida; além da estratégia de CQT (controle da qualidade total) e os CCQs (círculos de controle da qualidade), que agregam à função do operário a responsabilidade pela qualidade requerida na produção e seu controle imediato, incorporando as atividades de manutenção, acompanhamento e inspeção ao trabalho produtivo (Gounet, 2002). 
Assim, o enxugamento da estrutura organizacional (redução hierárquica e de funcionários), o alicerçamento da concorrência na criação de novas necessidades, a diversificação e personalização da oferta, os novos princípios de relações interpessoais e de participação no interior da empresa redirecionam a demanda sobre os trabalhadores e requerem um trabalhador mais escolarizado, com maior capacidade de raciocínio lógico, apto a operar equipamentos diversificados, com habilidade para relacionar-se com os colegas, firmado no tênue limite entre cooperação e competição, motivado para o trabalho, engajado com os objetivos da empresa, um colaborador.

Segundo Antunes (2005), enquanto o fordismo expropriou o "saber operário", transferindo-o para a gerência, o toyotismo apropria-se da dimensão intelectual, da capacidade cognitiva, envolvendo intensamente a subjetividade operária. Além do que, convoca a construção de uma "subjetividade inautêntica", aparentemente voltada para a qualidade, para o consumidor, para o produto, mas implícita e primordialmente engajada com a autoreprodução do capital.

Nessa perspectiva, as novas formas de produção não superam, mas apenas reeditam a relação de submissão do trabalho ao capital, fazendo emergir como único saldo negativo da produção flexível o ônus pago pelo trabalhador: desemprego, intensificação do trabalho, contrato temporário, terceirização, crescimento da economia informal, o solapamento das possibilidades de organização dos trabalhadores, ou simplesmente, a total precariedade das situações e formas de trabalho.

Portanto, a crise estrutural do capital e seu enfrentamento, expressos pela reestruturação produtiva e permeados pela hegemonia ideológica neoliberal, conduzem a uma lógica social que, focada no consumo, na mercadoria, no valor de troca, negligencia o sujeito, trazendo profundas conseqüências para todas as instâncias da vida social, precipuamente no interior do mundo do trabalho, com desdobramentos éticos, políticos e culturais.

Tais constatações autorizam afirmar que as formas de organização e estruturação social do trabalho não são apenas estratégias de gestão ou simples sistemas de produção, mas, antes de tudo, são um modo de vida, configurando-se como um processo perverso de subjetivação social.

\section{Assédio Moral no Trabalho}

O que neste momento denomina-se de assédio moral é também conhecido, entre nós, como terror psicológico ou violência psíquica e, em outros lugares, como mobbing (Itália, Alemanha e Escandinávia), harcèlement moral (França), acoso moral (Espanha), bulling (Inglaterra), moral harassment (Estados Unidos e Japão), entre outras denominações. Constituindo-se em um fenômeno social, a despeito das diferenças culturais, a rigor, refere-se aos atentados contra a dignidade humana, ocorridos de forma intermitente, que podem manifestar-se na família, na escola ou no trabalho.

Para o que aqui se pretende, aprofundar a compreensão do assédio moral no ambiente de trabalho, cabe inicialmente mencionar em linhas gerais a proposta percussora de Leymann, além das contribuições de Piñuel e Zabala (2003), Barreto (2003) e Heloani (2004), tendo em vista a influência destas últimas no direcionamento da discussão que aqui se propõe. Em seguida, apresentar-se mais detidamente a abordagem feita por Hirigoyen (2002, 2003). Essa opção foi feita sem a intenção de minimizar outras discussões que sabidamente têm colaborado para o debate e aprofundamento do tema. Levou-se em consideração a eminente repercussão e influência teórico-metodológica dessa abordagem, impulsionando e mesmo delimitando a discussão sobre o assédio moral em diversos países, inclusive no Brasil. 
Heinz Leymann, médico alemão e pesquisador em psicologia do trabalho, atuando na Suécia na década de 80 , estudou diferentes grupos profissionais e qualificou o processo encontrado de "psicoterror", introduzindo o conceito de mobbing para descrever formas de assédio ocorridas dentro das organizações. Como indica a origem do termo (mob: multidão, turba; Mob para designar "máfia"), trata-se de um fenômeno de grupo que corresponde a perseguições coletivas e violência, podendo incluir a violência física. Segundo o autor, o mobbing provém de um conflito que evolui e degenera, sendo uma forma grave de estresse psicossocial. Esse conceito difundiu-se a partir de 1993, com a publicação do livro Mobbing: a perseguição no trabalho.

O psicólogo Inaki Piñuel (Piñuel \& Zabala, 2003), professor da Universidade de Acalá, inaugura na Espanha a discussão sobre o assédio moral. Em sua obra Mobbing: como sobreviver ao assédio psicológico no trabalho, descreve como o assédio destrói a capacidade de trabalho e a resistência psicológica das vítimas. Caracteriza a ação do agressor, analisando as defesas e racionalizações por parte das vítimas que dificultam uma resposta ativa para sair do problema.

(...) intimidar, diminuir, humilhar, amedrontar e consumir emocional e intelectualmente a vítima, com o objetivo de eliminá-la da organização ou satisfazer a necessidade insaciável de agredir, controlar e destruir que é apresentada pelo assediador que aproveita a situação organizacional particular (reorganização, redução de custos, burocratização, mudanças drástica etc.) para canalizar uma série de impulsos e tendências psicopáticas (Piñuel \& Zabala, 2003, p. 32).

Nesse sentido, considera as organizações mais rígidas, burocratizadas, com sobrecarga de trabalho ou pouco enriquecimento das tarefas, nas quais persiste a falta de ética, como os locais em que mais se propaga o assédio. As vítimas, indivíduos disponíveis à mudança e à autocrítica, empáticos, éticos e com capacidade para a liderança informal, são percebidas como ameaças pelos agressores (indivíduos "menos capazes" ou que apresentam transtornos de personalidade ou alterações psicopáticas) e tornam-se alvos de ameaças, críticas infundadas, calúnias, manipulações e estigmatizações frente aos demais companheiros de trabalho. Piñuel declara que a luta contra o assédio moral no trabalho, além de sua pertinência quanto a questões éticas e humanitárias, é também uma forma de preservar a competitividade empresarial mediante a proteção do capital intelectual humano da organização. Para ele, a maior dificuldade para abordar e diagnosticar o assédio moral no trabalho está no fato de sua origem estar na empresa e não na vítima.

No Brasil, Margarida Maria Silveira Barreto (2003) tem como sua mais conhecida contribuição a ampla e expressiva pesquisa realizada com trabalhadores do setor químico e similares, que buscou compreender o sentido da humilhação no discurso sobre saúde, doença e trabalho construído e sustentado pelo adoecido. A partir do referencial filosófico de Espinosa e da teoria sócio-histórica de Vygotski, analisa a retórica discursiva dos sujeitos pesquisados, concluindo que a humilhação é patogênica e inscreve-se nas relações autoritárias de poder. Em seu entendimento, o assédio moral ou a violência moral no trabalho são a exposição de trabalhadores a situações vexatórias, constrangedoras e humilhantes, de forma repetitiva no exercício da função, caracterizando atitudes desumanas, violentas e antiéticas de um ou mais chefes contra o subordinado.

Roberto Heloani, autor do livro Gestão e organização no capitalismo globalizado: história da manipulação psicológica no mundo do trabalho (Heloani, 2003), fundamenta-se na concepção de que cada indivíduo é produto-produtor de uma construção sócio-histórica. Nessa obra, o autor analisa a subjetividade no trabalho a partir da avaliação das teorias e das práticas dos modelos de gestão, questiona a visão tradicional dos paradigmas administrativos e tecnológicos. Heloani caracteriza o processo do assédio moral pela intencionalidade de neutralizar certos indivíduos em termos de poder, por meio de sua constante e deliberada desqualificação e 
fragilização. Para ele, a perversão moral, aliada à hipercompetitividade do atual contexto de trabalho, estimula a instrumentalização do outro.

Por assédio em um local de trabalho temos que entender toda e qualquer conduta abusiva manifestando-se, sobretudo, por comportamentos, palavras, atos, gestos, escritos que possam trazer dano à personalidade, à dignidade ou à integridade física ou psíquica de uma pessoa, pôr em perigo seu emprego ou degradar o ambiente de trabalho (Hirigoyen, 2003, p. 65).

É com essa definição que a psicoterapeuta e vitimóloga francesa Marie-France Hirigoyen inicia o segundo capítulo de seu livro Assédio moral: a violência perversa no cotidiano, publicado originalmente em 1998. O livro enfoca a perversidade das relações estabelecidas entre os indivíduos diretamente envolvidos em uma situação de assédio. A autora prioriza os aspectos subjetivos e comportamentais que caracterizam a vítima e o agressor, visando primordialmente explicitar o sofrimento das vítimas. Em 2001, publica o livro Mal-estar no trabalho: redefinindo o assédio moral, no qual aborda especificamente o assédio nas organizações de trabalho, buscando "(...) explorar as 'margens' do assédio moral e, assim, conhecendo o contexto, ultrapassar a dialética excessivamente redutora do algoz e da vítima" (Hirigoyen, 2002, p. 11).

Hirigoyen (2002) foi precursora do termo "assédio moral". Segundo ela, a escolha do termo implicou em uma tomada de posição, tendo em vista a impossibilidade de estudar esse fenômeno sem levar em conta a perspectiva ética. Assim, enquanto "assédio" denota a qualificação psicológica, o significado "moral" trata efetivamente do bem e do mal, do que é considerado aceitável ou inaceitável em nossa sociedade. Nesse sentido, o conceito de assédio moral, no que se refere à vítima, remete ao desprezo, ao maltrato, à humilhação; e, no que se refere ao agressor, remete à intencionalidade de fazer mal a alguém.

De acordo com a abordagem de Hirigoyen (2003), o assédio moral nasce como algo inofensivo e propaga-se de forma silenciosa, sorrateira e traiçoeira. Em um primeiro momento, os dois protagonistas adotam uma atitude de "evitação do conflito": o agressor ataca com pequenos toques indiretos, uma mentira, uma afronta sutil, sem provocar abertamente o conflito. A vítima submete-se, preferindo não se mostrar ofendida e procura tentar um acordo a arriscar-se no conflito. Esses ataques, porém, vão se multiplicando e a pessoa é acuada, posta em situações de inferioridade, submetida a manobras hostis e degradantes de forma recorrente, por períodos cada vez maiores, o que pode chegar à violência manifesta.

A primeira fase constrói-se por meio de um processo de sedução, durante o qual a vítima é desestabilizada e perde progressivamente a confiança em si mesma. Nessa fase, trata-se primeiro de seduzi-la, enredá-la, para finalmente, controlá-la, retirando-lhe a liberdade. A sedução constrói-se sempre de maneira indireta buscando captar o desejo do outro.

(...) A sedução perversa atua utilizando os instintos protetores do outro. Essa sedução é narcísica: trata-se de buscar no outro o singular de sua fascinação, a saber, a imagem ideal de si. Por uma sedução em sentido único, o perverso narcisista busca fascinar sem se deixar prender. Para J. Baudrillard, a sedução afasta a realidade e manipula as aparências (...) é da ordem dos signos e dos rituais, e seu uso maléfico. A sedução narcísica apaga os limites, torna confuso o que é próprio e o que é do outro. Não está, no caso, entre os mecanismos da alienação (...) e sim no da incorporação com o objetivo de destruir (Hirigoyen, 2003, p. 108).

Mais contundente é Lucchesi (2002), ao explicar a origem etimológica do termo "sedução":

A palavra provém do latim seducere (sed + ducere). Sed, além de conjunção equivalente a "mas", atuava nos textos antigos como prevérbio, significando "separação", "afastamento", 
"privação"; e ducere queria dizer "levar", "guiar", "atrair”. Em síntese, portanto, "seduzir” era o processo pelo qual se atraía para privar o outro da autonomia de si, sob a promessa de possibilitar-lhe a experiência do prazer pleno (p. 1, grifos nossos).

Pela sedução e pela manipulação dá-se o enredamento, o qual consiste na influência intelectual ou moral que leva alguém a pensar, decidir ou conduzir-se de forma não espontânea, embora se considere livre para fazê-lo. $O$ enredamento se estabelece em uma relação de poder por dominação, na qual um segue o outro por dependência, por adesão e, porque sob medo, rende-se por cumplicidade, mais ou menos consciente. Inclui ameaças veladas ou intimidações para fazer prevalecer as idéias de quem seduz e controla.

Assim, retira-se da vítima todo o seu senso crítico, neutralizando o seu desejo, destituindo-a de sua individualidade, eliminando qualquer capacidade de defesa: "(...) ela está 'coisificada', (...) não é mais um alter ego. Ela suporta tudo e até mesmo sem participar" (Hirigoyen, 2003, p. 110).

A fase seguinte (da violência manifesta) é feita sob uma violência fria, de golpes sujos, de injúrias, de ameaças veladas, de olhares acusadores, de humilhações verbais, da depreciação de tudo que pertence ao outro ou diz respeito à vítima. O ódio do agressor, dissimulado na fase de sedução, agora manifesta-se abertamente, é desencadeado em resposta às reações da vítima. Essas atitudes do agressor têm em vista manter o controle sobre a vítima, seja por desarmá-la, seja por desencadear uma reação violenta da vítima contra o próprio agressor, invertendo a situação (agressor-agredido) e levando a vítima a sentir-se culpada, confusa e envergonhada de si mesma.

A partir dessa contextualização do processo, Hirigoyen (2003) afirma que o agressor é um perverso narcisista e a vítima ideal tem um caráter pré-depressivo. Nesse sentido, esclarece que o ataque perverso caracteriza-se por ter em mira as partes vulneráveis do outro, seja essa fragilidade constitucional ou relacional. A violência perversa confronta a vítima com sua falta, com seus traumas; ela excita a pulsão de morte que há em todo indivíduo, já que "(...) a relação com o perverso funciona como um espelho negativo: a boa imagem de si é transformada em desamor" (p. 154).

A vítima, para Hirigoyen (2003), não é em si mesma masoquista ou depressiva. Os perversos vão mobilizar e usar essas características que nela existem. Nas relações sadomasoquistas (no sentido freudiano), os protagonistas encontram prazer sob a violência, há uma simetria oculta, havendo a possibilidade para qualquer um de sair do jogo, se desejar. $\mathrm{Na}$ relação com o perverso não há simetria, há dominação real, impossibilitando a pessoa submetida de reagir, de fazer cessar a luta.

No ambiente de trabalho, as pessoas mais visadas para se tornarem vítimas são aquelas que apresentam certa capacidade de resistir à autoridade: os indivíduos acima dos cinqüenta anos, julgados menos produtivos e adaptáveis a novas formas de trabalho, tornam-se vítimas fáceis do assédio, mesmo porque temem o desemprego estrutural. As mulheres são também freqüentemente assediadas e de forma diferente dos homens: as ações contra elas têm uma conotação machista e sexista e invariavelmente evoluem para o assédio sexual. O assédio está, também, diretamente relacionado a todo e qualquer tipo de discriminação (racial, religiosa, por deficiência física, em função de orientação sexual), mesmo porque, como afirma Hirigoyen (2002), "(...) todo assédio é discriminatório, pois ele vem ratificar a recusa de uma diferença ou uma particularidade da pessoa (...)" (p. 103, grifos nossos).

As agressões podem ser horizontais (entre colegas) ou verticais e, neste caso, ocorre tanto de um superior contra um subordinado, quanto o inverso. Ações mais incisivas do agressor são: recusa de comunicação direta, omitindo informações ou negando esclarecimentos; desqualificação de atitudes ou serviços; descrédito em opiniões ou escolhas; isolamento; indução ao erro e, até mesmo, o assédio sexual.

\section{4}


Quanto às conseqüências para a vítima, elas vão desde alterações mais superficiais e imediatas, tais como: confusão mental, descrita pela própria vítima como dificuldade de pensar, como certo vazio na cabeça; confusão que gera estresse, reforçado pela dúvida (quanto à própria culpa e aos motivos da submissão) e pelo medo (da agressão). Tudo isso leva a vítima a isolar-se socialmente. Com o passar do tempo, tais alterações chegam, muitas vezes, a modificações psíquicas mais intensas: desvitalização, levando a um estado depressivo crônico; uma "rigidificação" da personalidade com o surgimento de traços paranóides, podendo chegar a uma autêntica patologia delirante, dentro de uma atmosfera de mania de perseguição, chamada de psicose alucinatória crônica.

No que se refere aos aspectos legais e à legislação criminal, a maior dificuldade para atribuição de penalidades está no alto grau de subjetivismo que permeia a questão, uma vez que o nexo causal (a relação entre o sofrimento da vítima e a agressão), indispensável na esfera criminal, nem sempre é aparente: "(...) tais humilhações são normalmente perpetradas 'com luvas', ou seja, sem deixar as digitais do agressor" (Heloani, 2004, p. 8).

Alice Monteiro de Barros (2004, pp. 20-21), juíza do TRT 3a Região, afirma que somente na virada deste século é que o tema passou a receber tratamento jurídico ou por meio da doutrina, da legislação ou da jurisprudência, salientando que é a necessidade de proteção à dignidade do empregado que fundamenta a ação legal e justifica a punição do assediador. Segundo ela, o conceito jurídico de assédio moral é difícil de ser elaborado, tendo em vista os "difusos perfis do fenômeno". Alguns doutrinadores enfatizam o dano psíquico acarretado à vítima, enquanto outros destacam a situação vexatória e o dano à imagem provocados pelo assédio moral. A juíza posiciona-se no que se refere à jurisprudência propriamente dita: "Quanto ao dano psíquico, nós o consideramos dispensável, data venia de inúmeras posições contrárias. O conceito de assédio moral deverá ser definido pelo comportamento do assediador e não pelo resultado danoso (...)", esclarecendo que, ao exigir o dano psíquico como o elemento alusivo indispensável, possibilita-se que fiquem sem punições as agressões que não tenham conseguido "afetar" psicologicamente a vítima.

A despeito das diversas dificuldades existentes, vários países já possuem leis específicas para criminalizar o assédio moral no trabalho. É o caso de Alemanha, Itália, França, Austrália, Estados Unidos e Suíça. No Brasil, inexiste legislação própria e a questão é tratada indiretamente, fazendo parte do acervo jurídico nacional dos direitos fundamentais. No artigo 5o da Constituição Federal, os parágrafos II e III abrangem os assédios sexual e moral, respectivamente; além do que o artigo 483 da CLT, os artigos 138, 139 e 140 (crimes contra a honra - calúnia, difamação e injúria) e o artigo 146 (constrangimento ilegal) do Código Penal, também podem ser aplicados ao assédio sexual.

Livros, artigos, folhetos explicativos, alertas televisivos, reportagens, entrevistas e depoimentos de vítimas e sites específicos sobre o assunto vêm sendo produzidos. De forma geral, existe um amplo movimento de divulgação quanto a caracterização do assédio moral, envolvendo a mídia, sindicatos de categorias específicas, o Estado e até mesmo as próprias empresas, todos imbuídos, cada um a seu modo, em esclarecer as conseqüências desse fenômeno sobre a saúde física e psíquica dos indivíduos.

Sem a pretensão de minimizar a importância dos debates e das ações conjuntas para o desvelamento dessas tramas sociais, cabe lembrar, todavia, o "poder manipulador" do ideário neoliberal dominante em seu processo de construção de indivíduos que se adaptem ao status quo capitalista. A ideologia da indústria cultural (Adorno, 1985) exige indivíduos plenamente enquadrados, docilizados e padronizados que favoreçam a ganância na extorsão da mais-valia, exigida pela acumulação do capital (Caniato, 2008). Assim, os discursos de "evitação do assédio" e outras "estratégias contra a opressão" configuram-se como máscaras ocultadoras da espoliação. Encobrindo o interesse em negligenciar mais ou menos intencionalmente as 
atrocidades no mundo do trabalho, pois há muito o homem deixou de ser o sujeito social e quem reina soberano é o "Senhor Capital" (Carone, 1991).

À própria psicologia enquanto ciência não cabe abster-se. Desse ponto de vista, urge ter em pauta os descaminhos que levam a manutenção dessa forma de ser-viver-dos-homens, envidar esforços na busca de respostas e renunciar ao silêncio cúmplice e ao conformismo conivente que permite que os homens continuem sendo maltratados sob as formas contemporâneas da organização do trabalho, sob a violência, a injustiça e a exclusão sociais.

É certo que a violência faz parte da própria condição humana, como o amor, o

ódio, o poder, a submissão, o orgulho, a inveja e tantas outras facetas da personalidade (...) Em um sistema em que a "racionalidade instrumental" se sobrepõe à "racionalidade comunicativa" (para usarmos a expressão de Habermas) (...), o que gera uma distorção comunicacional, a violência torna-se uma resposta a um sistema desumano e não pode ser considerada mero mecanismo individual. Em outras palavras, nesse processo a violência passa a ser uma perversão da perversão, ou seja, uma armadilha motivada pela crueldade do sistema (Heloani, 2004, p. 2).

\section{Psicodinâmica do Trabalho}

Embora a ênfase nas tramas socioculturais, sabidamente, perpassem os conceitos propostos pelo próprio Freud e por outros autores de abordagem psicanalítica, pode-se afirmar que nem sempre as teorias e práticas psicológicas se voltaram para os modos de organização da produção da subsistência humana enquanto mediadoras da constituição do psiquismo. Segundo Jacques (2003), as teorias psicológicas clássicas não viam um caráter essencial no trabalho. As contribuições de autores como Erikson (1972), Habermas (1982) e Dejours (1988) instigaram uma releitura teórica, viabilizando um novo olhar sobre as dimensões do trabalho, que vem cada vez mais reafirmando a sua essencialidade na constituição do sujeito e na sua inserção social como estratégia de saúde ou modo de adoecimento.

Christophe Dejours, psiquiatra e psicanalista francês, redireciona, na década de 80, o estudo das repercussões da organização do trabalho sobre o aparelho psíquico ao inaugurar a psicodinâmica do trabalho. Disciplina específica que se origina com base nos estudos precursores de Le Guillant, Friedman e Naville, entre outros, que permitiram estabelecer relações entre trabalho e psicopatologia.

A teorização da psicodinâmica do trabalho tem como vertente fundamental as categorias da psicanálise e, como referências, os conceitos ergonômicos de trabalho prescrito e trabalho real. Baseia-se, além disso, em uma análise sistemática da organização do trabalho e das relações de poder a ela inerentes, vinculando-se também à sociologia do trabalho.

A partir da psicodinâmica do trabalho, compreende-se que frente a uma agressão contra o ego, a defesa dá-se, primeiramente, pela produção de fantasmas, permitindo a construção de uma ligação entre a realidade, o desejo e a possibilidade de sublimação, de tal forma que é no espaço entre o prescrito e o real que pode ocorrer a construção da identidade no trabalho. O conflito entre a organização do trabalho e as exigências intrínsecas do funcionamento psíquico é reconhecido como sofrimento.

Dejours (1994) considera o sofrimento como inevitável e invariavelmente relacionado com a história singular de cada sujeito e o define "(...) como a vivência subjetiva intermediária entre doença mental descompensada e o conforto (ou bem-estar) psíquico (...)”. Nesse sentido, distingue dois tipos de sofrimento. Por um lado, o "sofrimento patogênico", que surge "(...) 
quando todas as possibilidades de adaptação ou de ajustamento à organização do trabalho pelo sujeito acabam por capturar o seu desejo e colocá-lo em concordância com o que esta organização quer dele, quando foram utilizados todos seus recursos e a relação subjetiva com a organização do trabalho está bloqueada (...)". Ou seja, apesar dos recursos defensivos, permanece um sofrimento residual. Por outro lado, quando as condições psicoafetivas ${ }^{3}$ permitem não a eliminação, mas a transformação do sofrimento em criatividade, tem-se o "sofrimento criador", aquele que "(...) beneficia a identidade (...), aumenta a resistência do sujeito ao risco de desestabilização psíquica e somática. $\mathrm{O}$ trabalho funciona, então, como um mediador para saúde (...)" (pp. 127-137).

O sofrimento causado pelas pressões no trabalho gera estratégias defensivas que podem ser construídas e empregadas pelos trabalhadores de forma individual ou coletiva, sem que o sofrimento seja descaracterizado: fenômeno intrínseco vivenciado subjetivamente e de forma singular.

A diferença fundamental entre um mecanismo de defesa individual e uma estratégia coletiva de defesa é que, enquanto uma vem da estrutura psíquica do indivíduo, persistindo apesar da ausência física de outros, a segunda depende de condições externas, tornando-se insustentável se não existir consenso. O que ocorre é que vários sujeitos, cada um na vivência de seu próprio sofrimento, são capazes de unir esforços em uma estratégia comum de defesa, a qual é coordenada e unificada pelas regras defensivas.

As estratégias coletivas de defesa levam a "eufemização da percepção" e funcionam por meio de um "retorno da relação subjetiva com as pressões patogênicas", inerentes ao modo de produção. Ou seja, os trabalhadores modificam, transformam a percepção que têm da realidade adversa colocando essa compreensão a seu serviço e assumem uma posição oposta à de vítimas passivas, assumem o papel de agentes ativos em uma atitude provocadora (Dejours, 1994, p. 130).

Ao conseguirem tornar as defesas rígidas, os trabalhadores hesitam questionar a

situação objetiva de trabalho, pois há um custo psicológico para sua construção. O indivíduo acaba interpretando que o sofrimento é o resultado do enfraquecimento da estratégia defensiva e não a conseqüência da maneira de como o trabalho está organizado. Essas estratégias defensivas difundidas/assimiladas pelo coletivo dos indivíduos se erigem, objetivando-se, e, embora alienantes, acabam sendo interpretadas, falsamente, como promessa de felicidade. Assim, a ideologia defensiva pode ser entendida como "(...) a defesa da defesa que é erigida em ideologia (...)” (Dejours, 1994, p. 130, grifos nossos).

A construção de uma ideologia defensiva, portanto, significa passar da ordem coletiva à ordem do grupo homogeneizado, padronizado. Conduzir-se do espaço da identidade singular reconhecida para o reduto do apagamento das diferenças e das originalidades.

(...) Entramos então na ordem da psicologia das multidões e das massas organizadas por palavras de ordem e por um imaginário perseguidor das diferenças susceptíveis de surgir entre os indivíduos do grupo e cultivando a homogeneidade e o conformismo. A violência se delineia inevitavelmente no horizonte em lugar da ação. Na violência do grupo, este encadeamento estará sempre em atividade, encadeamento sem o qual o sofrimento é capaz de iniciar outros processos que não são desencadeados através da violência, mas através dos projetos de transformação da organização do trabalho (Dejours, 1994, p. 131, grifos nossos).

Se, por um lado, as estratégias defensivas são necessárias à vida e à proteção da integridade psíquica e somática, por outro lado, contribuem para acomodação do sujeito às

\footnotetext{
3 Dejours (1994) denomina essas condições psicoafetivas de “(...) 'ressonância simbólica' entre o teatro da situação de trabalho atual e o teatro interno herdado do passado (...)"(p. 134). É a possibilidade de sublimação (tal como é descrita em psicanálise: mudança de objetivo da pulsão).
} 
pressões, constituindo-se em impedimento às mudanças. Assim, as pressões do trabalho têm a capacidade de gerar alienação e violência, embora o façam, não por meio da "interiorização" das pressões, mas por meio das estratégias de defesa contra o sofrimento. Coletivas ou individuais, elas sempre apresentam um risco potencial para a autonomia subjetiva e moral (Dejours, 2001).

Merlo (2002) refere-se à diferença entre defesas produzidas por sublimação (sofrimento criador) e defesas adaptativas que ocorrem por meio da repressão pulsional (sofrimento patogênico), esclarecendo que a sublimação garante, diante do sofrimento, uma saída pulsional não desestabilizante, permitindo a objetivação da "inteligência astuciosa" e da criatividade frente às dificuldades do real. A repressão pulsional, em contrapartida, expulsa o sujeito de seu desejo, favorecendo a vontade do outro, ou seja, conduz à lógica da alienação.

De acordo com os pressupostos da teoria de Dejours, não é possível evitar o

sofrimento no enfrentamento das condições de trabalho, mas apenas transformá-lo. Todavia, cabe lembrar que o sofrimento inerente ao viver humano remete à decadência do corpo e ao caminhar para a morte, bem como à impotência humana diante dos fenômenos da Natureza. O sofrimento que é imposto nas relações entre os indivíduos pela organização do trabalho e que vem sendo designado como assédio moral, é de natureza ética. É esse sofrimento ético, causa da violência nas relações de trabalho, que Dejours afirma ser possível transformar (Caniato, 2008).

Dessa forma, torna-se possível entender que a estrutura psíquica do homem é lábil e trafega por um fio tênue de possibilidades de discriminação ou de queda na alienação. Muitas vezes, as estratégias forjadas no coletivo de indivíduos acabam sendo formas alienantes de sustentação da opressão social e são mantenedoras de adaptações conformistas ou até mesmo perversas. Por outro lado, o apoio do coletivo organizado é necessário para continuar o trabalho, na tentativa de minimizar as pressões sofridas por cada um sob as formas atuais de organização do trabalho. Mais ainda: o diálogo entre iguais contribui para o desenvolvimento da capacidade de os indivíduos criarem regras coletivas que lhes favoreçam e, assim, alimentar uma força em busca da mudança, da superação.

Os trabalhadores, porém, não têm conseguido encarar a realidade hostil do mundo do trabalho. Hesitando em questionar as normas impostas pela organização do trabalho - criam e mantêm ideologias defensivas em suas atuações no trabalho -, temem o desemprego gestado pelas novas estratégias organizacionais que ameaça a própria sobrevivência. Individualmente, o sofrimento é vivido como incompetência e impotência subjetivas e, o pior: não fica evidenciada a matriz do sofrimento como originária de sua exposição passiva (sem questionamento e análise) às violências e injustiças do contexto social do trabalho. $O$ enfraquecimento na elaboração de estratégias defensivas (sublimadas) aumenta o padecimento individual e uma terrível inversão ocorre: o sofrimento deixa de ser reconhecido como decorrente das pressões do trabalho e o indivíduo permanece vivendo sob autopunição, enquanto se "esfola" para ser recompensado e premiado pelo status dentro da empresa, entendido como a garantia da promessa de felicidade que não consegue viver.

Ao abordar a violência e as injustiças sociais, Dejours (2001) analisa e interpreta a "banalização do mal" no sistema produtivo contemporâneo da sociedade neoliberal. O problema levantado é, portanto, o da tolerância e da cooperação na produção e difusão do "mal". É a sociedade como um todo ("as pessoas de bem") agindo em defesa dos princípios organizacionais, porém, em detrimento do sujeito social.

"Trabalho sujo" é a metáfora usada pelo autor para denominar o mal, a violência, a injustiça, o sofrimento infligido ao outro no cotidiano de trabalho: demissões, exigências de metas inexeqüíveis, intensificação do trabalho, atitudes discriminatórias e de desprezo, de grosserias, obscenidades contra as mulheres, ameaças e chantagens. Ele é, também, as falsas

\section{8}


promessas de assistência ou de ajuda para o re-emprego, as justificativas caluniosas para a incompetência, a inadaptabilidade, a lerdeza, a falta de iniciativa. É, ainda, precarizar os meios e as condições de trabalho para submeter o outro ou obrigá-lo a fazer coisas que ele próprio reprova moralmente. Qualifica-se então com mal todas essas condutas, quando elas são instituídas, públicas, deliberadas, admitidas ou reivindicadas, e até mesmo consideradas corajosas (Dejours, 2001).

Para Dejours (2001), os "líderes do todo estratégico", aqueles que intervêm efetivamente na construção da doutrina e na ação (os que concebem o sistema), estão nas "posições de perversos ou de paranóicos compensados" (pp. 75-78). Entretanto, essa postura psicopatológica não representa uma modalidade reativa global de seu funcionamento psíquico, mas um oportunismo defensivo mediante condições externas ameaçadoras, sendo uma maneira de se haver com as obrigações morais por meio de uma duplicidade de conduta ("clivagem do ego").

Nesse sentido, o autor afirma que a colaboração voluntária e ativa na mentira e na injustiça “(...) é de uma maioria de sujeitos que não são perversos nem paranóicos, ou seja, que não apresentam maiores distúrbios do senso moral (...)", embora o processo funcione a base de uma subversão de valores. Subversão cuja análise remete diretamente à dimensão ética, mas também, refere-se ao "pático": a conduta em função da racionalidade pática dá-se em detrimento da conduta da racionalidade moral-prática, levando ao triunfo da racionalidade estratégica (realismo econômico-científico).

O "cinismo viril" é a estratégia coletiva de defesa, na qual a experiência do fracasso ("castração simbólica") é objeto de uma negação e uma racionalização coletivas, mobilizadas para enfrentar o sofrimento gerado pelo medo, conduzindo a participação ou tolerância no/do "trabalho sujo", as quais erigem-se em "ideologia defensiva do realismo econômico". Dessa forma, na ideologia defensiva do cinismo viril a racionalização pelo econômico é uma forma de domínio simbólico típico do gênero masculino ${ }^{5}$, objetivando-se por meio da afirmação do cinismo como força de caráter, senso de responsabilidade coletiva e da exacerbação da virilidade sob o respaldo de uma racionalidade econômica ou científica (racionalidade estratégica).

A virilidade é concebida socialmente como um atributo sexual que confere à identidade masculina a capacidade de expressão do poder. Associada ao exercício da força, da agressividade, da violência, da dominação, obtém garantia de segurança e proteção para o sujeito e para os que lhe são chegados, estando simbolicamente associada ao medo e à luta contra o medo, ou seja, a coragem. A virilidade é considerada como uma qualidade, uma virtude: eis aí racionalização do "mal" no "bem", na qual a ética (racionalidade moral-prática) não é abolida, mas invertida.

A coragem, em estado puro, tem a ver com a autonomia moral-subjetiva, dispensando o reconhecimento alheio, é uma conquista individual diante da neutralização do medo. Via de regra, manifesta-se silenciosamente e é julgada pela própria consciência. Já a virilidade, é uma conduta cujo mérito está na validação alheia. A "coragem viril" por sua vez, necessita de uma platéia, de demonstrações, evidenciando-se não apenas nas condutas e comportamentos, mas também e fundamentalmente na ordem do discurso. O "discurso viril" é apoiado no conhecimento, na comprovação técnico-científica, no raciocínio lógico, visando afastar toda ameaça de fraqueza ou fracasso, é um discurso de domínio sobre o mundo.

\footnotetext{
4 “(...) aquilo que concerne à preservação do eu (saúde física e mental) ou a realização do eu (construção subjetiva da identidade)” (Dejours, 2001, p. 81).

5 Gênero remete à construção social de condutas identificadas como femininas ou como masculinas. Em psicodinâmica do trabalho, virilidade refere-se ao gênero masculino e mulheridade ao gênero feminino.
} 
O resultado social e político da conotação sexual associada à capacidade de usar a força e a violência contra outrem deixa aquele que se recusa a cometer tal violência numa situação psicológica perigosa: (...) alguém que não merece ser reconhecido como pertencente à comunidade dos homens (...) é um sinal patente de covardia (Dejours, 2001, p. 85).

A renúncia a exercer a força, a agressividade, a violência e a dominação, nos termos do discurso organizacional, é transfigurada: trata-se de falta de atitude, de liderança, incapacidade de assumir responsabilidades, inabilidade para trabalhar em equipe, desmotivação para o trabalho ou, simplesmente, incompetência profissional.

A radicalização das estratégias de defesa culmina na adesão ao ideário erigido pelo capitalismo contemporâneo, sustentado por uma cultura do desprezo e da exclusão do humano dos homens, superado pela lógica do "ter dinheiro". Necessário se torna deslocar para os indivíduos a culpabilização pelos seus fracassos o que, além de potencializar seus sofrimentos, encobre e sustenta as calamidades, que continuam sendo produzidas pela organização do trabalho.

\section{Considerações finais}

Hirigoyen $(2002,2003)$ e Dejours $(1988,1994,2001,2006)$ analisam o processo de espoliação do trabalhador tendo como base conceitual os pressupostos teóricos da psicanálise. A primeira, discute esse processo como uma perversão do ego (do agressor), priorizando o sofrimento da vítima, e interpreta esse sofrimento como conseqüência da violência a ela infligida. Já o segundo, entende o sofrimento como um sentimento singular vivenciado tanto pela vítima, quanto pelo agressor, interpretando a violência (mal instituído, "trabalho sujo") como uma conseqüência das estratégias de defesas, mobilizadas contra o sofrimento psicológico gerado pelo medo de ter medo (cinismo viril). Segundo Merlo (2002), o campo da psicodinâmica do trabalho é o campo do sofrimento: o conteúdo, a significação e as formas desse sofrimento e sua investigação situam-se no âmbito do "infrapatológico" ou "prépatológico", conduzindo a um novo enfoque da relação saúde-doença-trabalho.

Assim, grosso modo, pode-se dizer que, enquanto Hirigoyen parte de uma abordagem essencialmente individualizada, sob um ponto de vista psicopatológico, Dejours dá ênfase aos desdobramentos das relações de poder e dominação objetivados no âmbito sócio-econômico, por meio das adversidades impostas pelo trabalho prescrito.

Historicamente falando, a humilhação, a injustiça e a exclusão sociais, o mal deliberado e consentido, ou o assédio moral, como queiram, ao contrário do que possa parecer, não são fatos recentes, pois sempre existiram nas mais diversas formas de objetivação social. De acordo com Heloani (2004), o assédio moral no trabalho pode ser entendido como uma nova discussão sobre um velho fenômeno. Um problema tão antigo quanto o próprio homem. Isso não significa negar a especificidade com que se manifesta na contemporaneidade nem mesmo minimizar as graves conseqüências psíquicas de seus desdobramentos. Em contrapartida, implica reconhecer a necessidade eminente de encontrar caminhos que venham transpor os limites impostos pelo dualismo saúde-doença, buscando respostas em suas diferentes articulações subjetivas, sociais e éticas.

Nesse sentido, é significativo o desvelamento do panorama ideológico desse processo, cuja atualização concretiza-se pela violência social, paradoxalmente, culpabilizando os indivíduos a pelos sofrimentos a eles infligidos (Caniato, 2008).

No trabalho humano está, ou deveria estar, algo que define a ação do homem sobre o mundo como atividade mediadora de sua humanização: a consciência e a intencionalidade. 
Nesse contexto, finalidade e produto remetem, ou deveriam remeter, à objetivação do empreendimento do homem para os homens. Contudo, o trabalho na sociedade moderna estruturado sob os ditames do ideário neoliberal e das imposições do modos de organização do processo produtivo capitalista, vem sendo destituído de seu caráter criativo e livre inerente à atividade humana. Assim, expropria o sujeito do conteúdo de seu esforço produtivo e prioriza o consumo no pós-trabalho. Transfigurado em movimentos estranhados, preestabelecidos, repetitivos e fragmentados, não serve ao desenvolvimento dos homens. Esvaziado de significação subjetiva, remete à banausia no entendimento de Aristóteles, à alienação para Marx e à estratégia coletiva de defensa na análise de Dejours.

Mediante o que foi colocado, é possível entender o assédio moral como uma violência psíquica, um cerceamento da autonomia do indivíduo e da constituição de vínculos de alteridade, que se caracteriza, fundamentalmente, pela domínio e controle da ação laboral do sujeito social. No âmbito da organização produtiva, mais que a espoliação da força de trabalho e as restrições às suas condições materiais de sobrevivência, as adversidades impostas aos indivíduos exprimem a expropriação da possibilidade humana de tornar-se protagonista de sua própria existência, de singularizar-se e de desenvolver a sua alteridade em laços de confiabilidade e acolhimento com os seus semelhantes.

Ao finalizar, cientes da amplitude e da complexidade do tema que deflagrou o estudo em questão, o sofrimento do homem no trabalho, considera-se, todavia, que os conceitos abordados, bem como a discussão proposta, sejam suficientes para instigar novas reflexões. Espera-se que elas possam contribuir para o encaminhamento de ações mais efetivas quanto ao fenômeno social que vem sendo denominado de assédio moral no trabalho.

\section{Referências}

Adorno, T. W. \& Horkheimer, M. (1985). Dialética do Esclarecimento: fragmentos filosóficos. Rio de Janeiro: Zahar.

Antunes, R. (2005). Os sentidos do trabalho: ensaio sobre a afirmação e a negação do trabalho. São Paulo : Boitempo.

Barreto, M. M. S. (2003). Uma jornada de humilhações. Dissertação de Mestrado, Faculdade de Psicologia, Pontifícia Universidade Católica de São Paulo, São Paulo.

Barros, A. M. (2004). Assédio moral. I Congresso sobre “A saúde mental no trabalho”. Goiânia, Brasil.

Caniato. A. (2008). Violências e subjetividades: indivíduo contemporâneo. Psicologia $\mathbb{E}$ Sociedade, 20 (1), 16-32.

Carone, I. (1991). De Frankfurt a Budapeste: os paradoxos de uma psicologia de base marxista. Psicologia USP, 2 $(1-2), 111-120$.

Carone, I. (2005). Práxis: da origem aristotélica aos nossos dias. São Paulo. [digitado]

Cattani, A. D. (Org.) (2002). Dicionário crítico sobre trabalho e tecnologia (4⿳⺈⿴囗十一 ed. rev. ampl.) Petrópolis: Vozes. Porto Alegre : UFRGS.

Cunha, A. G. (1986). Dicionário etimológico nova fronteira da língua portuguesa (2a ed.). Rio de Janeiro: Nova Fronteira.

Dejours, C. (1988). A loucura do trabalho: estudos de psicopatologia do trabalho (3ª ed.). São Paulo: Cortes/Oboré (Originalmente publicado em 1980)

Dejours, C., Abdoucheli, E. \& Jayet, C. (1994). Psicodinâmica do trabalho: contribuições da escola dejouriana à análise da relação prazer, sofrimento e trabalho. São Paulo: Atlas.

Dejours, C. (2001). A banalização da injustiça social (4⿳亠丷a ed.). Rio de Janeiro: FGV (Originalmente publicado em 1998. Título original: Souffrance em France; a la banalisation de l'injustice sociale).

Dejours, C. (2004). Subjetividade, trabalho e ação. Revista Produção, 14 (3), 27-34.

Gounet, T. (2002). Fordismo e toyotismo na civilização do automóvel. São Paulo: Boitempo. 
Heloani, J. R. M. (2003). Gestão e organização no capitalismo globalizado: história da manipulação psicológica no mundo do trabalho. São Paulo: Atlas.

Heloani, J. R. M. (2004). Assédio moral: um ensaio sobre a expropriação da dignidade no trabalho. Revista de Administração de Empresa, 3 (1), 1-8.

Hirigoyen, M. F. (2002). Mal-estar no trabalho: redefinindo o assédio moral. Rio de Janeiro: Bertrand.

Hirigoyen, M. F. (2003). Assédio moral: a violência perversa no cotidiano (6 $6^{\mathrm{a}}$ ed.). Rio de Janeiro: Bertrand.

Jacques, M. G. C. (2003). Abordagens teórico-metodológicas em saúde/doença mental \& trabalho. Psicologia $\mathcal{E}$ Sociedade, 15 (1), 97-116.

Liedke, E. R. (2002). Trabalho. In A. D. Cattani (Org.), Dicionário crítico sobre trabalho e tecnologia. (4⿳亠丷a ed. rev. Ampl., pp. 341-346). Petrópolis: Vozes; Porto Alegre: UFRGS.

Luchesi, I. (2002). A mídia e a sedução sem encantamento. Observatório da Imprensa, 1. Artigo disponível na internet: http://observatorio.ultimoesgundo.ig.com.br/artigos/jd060320024.htm [08/01/2008]

Magalhães, A. (1958). Dicionário enciclopédico brasileiro. Rio de Janeiro: Globo.

Merlo, A. R. C. (2002). Psicodinâmica do trabalho. In M. G. C. Jacques \& W. Codo (Orgs.), Saúde mental $\mathscr{E}^{2}$ trabalho: leituras (pp. 130-136). Petrópolis: Vozes.

Piñuel, I., Zabala, A. \& Cantero, A. O. (2002). La incidencia del mobbing o acoso psicológico en el trabajo en España. Lan Harremanak: Revista de Relaciones Laborales, 7 (2), 35-62, 1.

Piñuel, I. \& Zabala, A. (2003). Mobbing: como sobreviver ao assédio psicológico no trabalho. Loyola.

\section{Endereço para correspondência}

ampicani@onda.com.br, licl@bol.com.br

Recebido em: 27/02/2008

Revisado em: 14/04/2008

Aprovado em: 15/06/2008 